\title{
FINANCIAL STRATEGY AND THE PROCESS OF THE INTERNATIONALIZATION OF ENTERPRISES
}

\author{
Jerzy Różański \\ University of Lodz, Lodz, Poland \\ e-mail: jerzy.rozanski@uni.lodz.pl \\ ORCID: 0000-0003-3222-209X
}

\section{Justyna Bogołębska}

University of Lodz, Lodz, Poland

e-mail: justyna.bogolebska@uni.lodz.pl

ORCID: 0000-0002-3730-1849

(C) 2020 Jerzy Różański, Justyna Bogołębska

This work is licensed under the Creative Commons Attribution-ShareAlike 4.0 International License. To view a copy of this license, visit http://creativecommons.org/licenses/by-sa/4.0/

Quote as: Różański, J. i Bogołębska, J. (2020). Financial strategy and the process of the internationalization of enterprises. Financial Sciences, 25(4).

DOI: $10.15611 /$ fins.2020.4.04

JEL Classification: 2003

\begin{abstract}
The article presents preliminary research on the financial strategy of enterprises in the process of internationalization. Using the survey as a research method, 25 enterprises that export their products outside Poland were examined. The main hypothesis is that the economic crisis caused by the pandemic will not lead to a change in the significance of factors influencing the enterprises' financial strategy, and in particular to the change in the relationship between internationalization and an enterprise's financial strategy.
\end{abstract}

Keywords: internationalization, enterprise, financial strategy.

\section{Introduction}

The processes currently occurring in the world economy are complex. On the one hand, one is dealing with the progressive liberalization of the economy, on the other, with autarkic tendencies caused by a number of reasons, some of which could have been predicted (securing workplaces in a given country, fears of excessive dependence on the supply of raw materials and finished products from specific countries, e.g. goods from China or energy resources from the Russian Federation), others, such as the COVID-19 pandemic, were difficult to anticipate. However, can it be concluded 
that the era of globalization of the world economy is over? The most likely is the scenario in which this will depend on the sector of the economy. Strategic sectors will be embraced with more detailed protection than before, while the needs related to innovation, new technologies, creation of new products and services will force many enterprises to enter global strategic alliances, build cross-boundary networks and internationalize their activity. Searching for new sales markets, creating particularly favourable conditions for starting and continuing economic activity on the part of the host countries, and needs related to extending the product life cycle, will encourage capital expansion beyond the borders of the home country. The most pronounced research gap seems to be related to examining the relationship between changes caused by the internationalization process of an enterprise and changes in its financial strategy.

The authors decided to investigate this problem taking into account the possibility of the substantial differences in the financial strategy adopted by Polish enterprises in the period before the outbreak of the virus epidemic and afterwards, i.e. during the economic crisis caused by the pandemic. It will attempt to examine the threats, but also the opportunities faced by Polish enterprises, and answer the following questions: "Will their role in the internationalization processes change?", and "Will they be forced to change their financial strategy?". The authors understand financial strategy as:

- shaping the volume of capital needs,

- the strategy in obtaining financing sources, and thus creating the capital structure of enterprises,

- the principle of creating funds and allocating available financial resources.

There is a lack of both theoretical studies and empirical research on this subject. Undertaking research in this area is associated with the need to set basic priorities. Therefore the main goal, main hypothesis and auxiliary hypotheses were formulated, which will facilitate profiling the whole research. The main hypothesis is: The economic crisis caused by the pandemic will not lead to the altering the significance of the factors influencing the enterprises' financial strategy, and change in the relationship between internationalization and an enterprise's financial strategy.

\section{Analysis of the literature on the subject in the field of internationalization and financial strategy}

Up till now interest in the issue of changes in financial strategy in connection with the internationalization processes of an enterprise has been minimal and the research directions regarding enterprises' internationalization processes have focused on:

- defining the stages of enterprises' internationalization, i.e. the Uppsala model (Johanson \& Vahln, 1977, 2009) - assuming the gradual entry of enterprises into the internationalization process with subsequent concepts (Dunning \& Lundan, 2008). It is worth emphasizing that other concepts presented the possibilities of this process 
going backwards, i.e. de-internationalization (Welch \& Luoristarinen, 1998), as well as the possibility of reinternationalization (Vissak \& Francioni, 2013);

- the possibility of rapid internationalization - the concept of born global (Baronchelli \& Cassia, 2010; Jantunen, Nummela, Puumalainen, \& Caarenketo, 2008; Knight \& Cavusgil, 2004);

- creating models of international business networks (Johanson \& Vahlne, 2009);

- examining the relationship between these processes and the overall strategy of an enterprise (Frynas \& Mellahi, 2011).

The presented literature review concerns the process of internationalization as a whole and includes examples of literature on the inflow of foreign investments to Poland. Some very valuable research attempts were also carried out in Poland. The basic research trends in our country include:

- relations between a foreign investor and a host country, taking into account the motives for internationalization and incentives applied by the host country towards a foreign investor, including the theory of special economic zones (Dorożyński, 2018; Gorynia, 2007; Karaszewski, 2013; Rymarczyk, 2004);

- research on foreign investments in underdeveloped areas (Bojar, 2001);

- foreign investments efficiency calculus (Jaworek 2013; Różański, 2010);

- analysis of capital and non-capital forms of foreign expansion (Poniatowska-Jaksch \& Pakulska, 2009);

- dependencies between the progress of internationalization and the financial results of enterprises (Barłożewski, 2017).

There is also the theme of financial strategies related to international expansion.

The research in this area focused on:

- the debt ratio of international companies according to the agency theory (Chiung-Jung \& Chwo-Ming, 2011);

- the impact of foreign investments and the degree of export advancement on the capital structure (Chiung-Jung \& Chwo-Ming, 2011);

- determining the degree of internationalization of an enterprise in the context of agency costs and capital structure (Hitt, Hoskisson, \& Kim, 1997);

- studying the degree of debt of international enterprises compared to domestic enterprises (Burgman, 1996; Chen, Cheng, He, \& Kim, 1997, Doukas \& Pantzalis, 2003; Singh \& Nejdmayeri, 2004);

- examining the capital structure in international enterprises (Fatemi, 1988; Hughes, De Louge, \& Seeney 1975; Lee \& Kwok, 1988; Michel \& Shaked, 1986; Shapiro, 1978);

- studying the increase in the value of financial leverage among enterprises that internationalize their activity (Chen et al., 1997; Chkir \& Cosset, 2001); it is worth noting that these studies cover only some aspects of the financial strategy of enterprises, without defining its overall relationship with the internationalization process.

Therefore the adopted research hypotheses and the main research goal link the internationalization process of an enterprise with the individual manifestations of 
changes in its financial strategy (changes in the capital structure, in the volume of financing, and in the creation and spending of company funds). As already mentioned, the research would thus be completely innovative, due to the general lack of this type of research in Polish and world literature. The importance of these issues for the development of social sciences, and especially the discipline of economics and finance, cannot be underestimated. The point being that the research in question can contribute to the determination of certain regularities related to the shaping of the financial strategy of an enterprise, and serve to expand knowledge connected with the processes occurring during internationalization, which facilitates the development of economics, but also determines changes in the financial strategy occurring under the influence of these processes, and therefore it involves references to the finances of an enterprise. The value of the research includes determining the strength of the impact of individual factors on the financial strategy in stable conditions and in conditions of economic turmoil. In the existent literature on the subject, only one attempt has been made to evaluate the financial strategy based on empirical research (Svatosova, 2017). The sample in that study concerned small and medium enterprises from the agrotourism sector, and included 21 observations in the period 2010-2014.

\section{Research methods and the course of the research process}

The survey was conducted in 2020. The scope of the study and the deliberate selection of a sample at the level of 25 enterprises is typical of preliminary studies. The subject of the study was the export activity of enterprises and the related financial strategy, for which 25 interviews were conducted. The selection of the sample was deliberate. The research was conducted by an external company on behalf of the authors. The research contractor was selected on the basis of the submitted response to the inquiry. The study began in February 2020 and ended in June 2020. The research tool was a survey, which consisted of eight open-ended questions and four questions related to the characteristics of a given enterprise (year of establishment company, number of employees, declaration regarding conducting export activity, legal form). It was assumed that the research sample would include only enterprises that conduct export activities. Additionally, it was also assumed that the group should be diversified in terms of the number of people employed and the length of the business operation. The study was carried out using the CATI method.

\section{Empirical study of the internationalization process and changes in the financial strategy}

In the conducted basic research, the respondents indicated regions where they conduct their export activities. The respondents indicated all regions in which export activities are currently conducted, it was possible to select more than one answer. 
Table 1. Countries/continents in which enterprises conduct export activities

\begin{tabular}{|l|c|c|c|c|c|c|}
\hline \multicolumn{1}{|c|}{ Country/continent } & Poland & Europe & America & Asia & Africa & Australia \\
\hline Response number & 25 & 24 & 9 & 15 & 6 & 3 \\
\hline
\end{tabular}

Source: own research.

Europe is the most important export area. The respondents did not indicate exactly in which countries they export. In other variants of the answers regarding the reasons why the company decides to export its products, the respondents indicated: obtaining better prices, starting a new investment, developing the company, gaining new markets, increasing revenues, improving the image and competitiveness, access to new technologies, global markets, there was also a demand for the company's products, acquiring new customers, and increasing sales.

Table 2. The most important reasons for undertaking export activity

\begin{tabular}{|c|c|c|c|}
\hline $\begin{array}{c}\text { Higher prices } \\
\text { achieved abroad }\end{array}$ & $\begin{array}{c}\text { Strong competition in } \\
\text { the domestic market }\end{array}$ & $\begin{array}{c}\text { Access to raw materials and labour outside } \\
\text { the domestic market }\end{array}$ & Other \\
\hline 14 & 8 & 12 & 13 \\
\hline
\end{tabular}

Source: own research.

In Table 3 the respondents indicated their motives for undertaking activities related to internationalization. It was possible to give more than one answer in the given answers. Therefore, it should be considered that the most important factor influencing the willingness to take actions related to internationalization is the possibility of obtaining a higher price of the sold product compared to the domestic market. Another question in the survey concerned the planned further development of the company. A follow-up question was also included regarding the internationalization phase of the company at the time.

A group of 14 respondents (the survey was conducted among 25 companies) made changes in the structure of production (services provided), seven respondents planned these changes in the future, while four respondents declared no such changes, but took into account in the answer that such changes were not needed due to the internationalization of the enterprise, because from the very beginning of the company's operations the internationalization process was included in its strategic goals and activities. During the survey, ten respondents confirmed changes in the financial structure. The changes in the structure of financing sources mainly consisted in: acquiring new shareholders, introducing additional capital by the partner that had been invested, there was a relocation of funds within the company, there was an increase in own funds, an investment loan was introduced, EU funds were obtained (four respondents), an investment fund that had invested its resources. On the other hand, a group of ten respondents concluded that there was no need to introduce such 
Table 3. The current stage of internationalization in the enterprise

\begin{tabular}{|c|c|}
\hline Respondent & $\begin{array}{l}\text { Is the internationalization phase of the enterprise the target or are further phases } \\
\text { planned? }\end{array}$ \\
\hline 1 & development, we want to enter new markets, \\
\hline 2 & we are planning further development, certainly including new technologies \\
\hline 3 & $\begin{array}{l}\text { we want to establish cooperation with new countries, planned entry into Asian } \\
\text { markets and obtain better prices }\end{array}$ \\
\hline 4 & we are planning further phases \\
\hline 5 & $\begin{array}{l}\text { further development is planned, cooperation with new countries, extension of the } \\
\text { product offer, new customers and new markets, new recipients of services }\end{array}$ \\
\hline 6 & we plan further development, both in terms of services and markets \\
\hline 7 & it is probably never that targeted, we want to develop all the time \\
\hline 8 & we are planning development, we want to enter new countries in Asia \\
\hline 9 & $\begin{array}{l}\text { planned further development, plant expansion, new markets and investments in } \\
\text { machinery }\end{array}$ \\
\hline 10 & $\begin{array}{l}\text { I don't know if we will ever say that a given phase was the target phase, we are still } \\
\text { developing and we are not going to rest on our laurels }\end{array}$ \\
\hline 11 & $\begin{array}{l}\text { exports already cover the whole world, but we continue to strive to modernize both } \\
\text { production and technology }\end{array}$ \\
\hline 12 & we are planning further phases, mainly related to new markets and maybe products \\
\hline 13 & $\begin{array}{l}\text { planned further development, expansion of the product offer to more countries, we } \\
\text { also improved our production capacity and increased our product offer }\end{array}$ \\
\hline 14 & planned further development, extension of the product offer, entry into new markets \\
\hline 15 & $\begin{array}{l}\text { we plan further phases, including the purchase of semi-finished products from other } \\
\text { markets }\end{array}$ \\
\hline 16 & $\begin{array}{l}\text { we want to develop all the time, it is necessary in business, because if you stand still, } \\
\text { it moves backwards, the competition is not asleep }\end{array}$ \\
\hline 17 & $\begin{array}{l}\text { planned further development, cooperation with more countries, international } \\
\text { cooperation in the field of research and development, entering new markets, } \\
\text { increasing the position on the domestic and world markets }\end{array}$ \\
\hline 18 & we plan further development and gaining new markets \\
\hline 19 & so far we are not planning any new stages, but nobody said it would not change \\
\hline 20 & $\begin{array}{l}\text { planned further development, increasing the number of countries and research units } \\
\text { in terms of cooperation }\end{array}$ \\
\hline 21 & yes, we are planning to enter selected Asian countries at the moment \\
\hline 22 & further development is planned, increasing the range, increasing competitiveness \\
\hline 23 & we are planning further development, expanding contacts with more countries \\
\hline 24 & we are planning further phases \\
\hline 25 & we are not planning further phases \\
\hline
\end{tabular}

Source: own research.

changes because the company's development strategy assumed its internationalization, without the need to change the financial structure. In order to complete the information on the structure of financing sources, the respondents also answered the question 
whether they plan to change the sources of financing the enterprise - seven answered in the affirmative, one question remained unanswered because the respondent treated it as the company secret, the remainder did not plan any changes in the area of sources financing. The types of planned changes in the sources of financing included: obtaining EU funding for development and new technologies, planned attempts to obtain government subsidies for further investments, obtaining funds from the new Horizon Europe program. The study also asked a question about the creation of new special purpose funds (reserve fund, funds dedicated to specific investment and development projects). New special purpose funds were created according to 13 respondents. Target funds are most often associated with: investment in new technologies with a budget in excess of PLN 1 million a year, a fund for new investments, the size of which depends on the profit generated in the previous year, a target fund for the improvement of production processes and their functionality, a budget is planned depending on the needs, which is in the range of PLN 1-2 million. In a situation where this budget does not exist, all investment objectives are financed from own resources (two answers). Two respondents gave the amount of special purpose funds, each of them exceeded PLN 1 million. The survey also asked about the goals: for what purposes has the company already spent money in connection with the internationalization of the company's operations and in what amount? According to the answers given by the respondents, the most capital-intensive tasks related to the internationalization process were: purchase of raw materials, trips, additional training, promotions, purchase of machinery (over PLN 200,000 - two answers), new technologies, investments in machinery, employee training, purchase new technologies, acquiring new contractors (approximately PLN 300 thousand one answer), certificates, purchase of new machines (approximately PLN 700 thousand - one answer), organization of conferences, employee mobility, new publications, new strategic partnerships (approximately PLN 50 thousand PLN one answer). In connection with the survey conducted in this way, a question was also asked about the assessment by enterprises of the effectiveness of the introduced internationalization strategy.

Table 4. Internationalization strategies that occur in enterprises

\begin{tabular}{|c|c|c|c|}
\hline Assessment of a given strategy & Offensive & Moderate & Conservative \\
\hline Number of responses & 4 & 18 & 3 \\
\hline
\end{tabular}

Source: own research.

When answering the question about the strategy, the respondents also had the opportunity to complete the information and add a comment in connection with the company's strategy. In the context of the offensive strategy, the respondents stated that:

- "we are striving to increase our presence with new markets, new countries and expansion of the product offer", 
- "we invest a lot, because we hope it will bring benefits",

- "we undertake activities that go beyond the basic activity in relation to new markets, new products, new technologies",

- "we broaden our horizons, we constantly develop, we enter new markets, we invest in the hope that it will pay off".

On the other hand, the comments of the respondents who used the moderate strategy were as follows:

- "this option is reasonable",

- "moderate realism is advisable and our development shows that we have chosen the right strategy",

- "we have been on the market for a long time and you can see that our strategy is good",

- "market observation both in the economic and political spheres, responding to customer needs",

- "we rely on a thorough and detailed analysis",

- "it depends on the economic situation, when we see an upward trend, we act aggressively",

- "such a strategy is safe, but also developmental".

Table 5. Categories of activities carried out in the enterprise in connection with the adopted strategy

\begin{tabular}{|c|c|c|c|c|c|c|}
\hline $\begin{array}{c}\text { Pricing } \\
\text { policy }\end{array}$ & $\begin{array}{c}\text { Finance } \\
\text { and inventory } \\
\text { management }\end{array}$ & $\begin{array}{c}\text { Cost } \\
\text { strategy }\end{array}$ & $\begin{array}{c}\text { The size } \\
\text { of the } \\
\text { margin }\end{array}$ & $\begin{array}{c}\text { Credit } \\
\text { policy }\end{array}$ & $\begin{array}{c}\text { Farming - } \\
\text { subsidy with } \\
\text { financial means }\end{array}$ & $\begin{array}{c}\text { Relationships } \\
\text { between receivables } \\
\text { and liabilities }\end{array}$ \\
\hline 22 & 22 & 18 & 14 & 7 & 19 & 15 \\
\hline
\end{tabular}

Source: own research.

The comments of the remaining respondents regarding the applied strategy were similar to those presented above. The fear of risk was the most common argument supporting this kind of choice in the situation of applying a conservative policy. Due to the internationalization strategy pursued by enterprises, the respondents were also required to define what activities it was related to.

\section{Conclusion}

The research concerned all phases of internationalization, but Polish enterprises have entered the first phase of the process, i.e. exporting. It seems that the number of countries to which a company exports does not depend on the length of its operation. The export activity is implemented both by enterprises with a short market history and those operating for many years in a given industry. The choice of European countries as the most important areas of export activity may be determined by the distance and logistic capabilities (costs) of enterprises (Table 1). The most frequently 
mentioned motive for undertaking export activities by enterprises was the possibility of achieving higher selling prices of the offered products, compared to the same products sold in Poland (Table 2). This situation may change significantly when Poland joins the eurozone. The group of respondents differed in the length of running an enterprise, so it can be assumed that it was also diversified in terms of the stages of introducing particular stages of internationalization. The vast majority of respondents declared a willingness to further develop in the area of the internationalization of their business activities (Table 3). The responses also included indications of the next country to which their products are to be exported. The discrepancy in the development of the export plans of the enterprises indicates that logistic costs and distance do not determine the choice of the enterprise's development in the context of exporting its products. The global situation related to the pandemic, the slowdown in economic development of many countries, and the decline in consumption, are the events that should have a negative impact on enterprises inhibiting or limiting the desire to develop. The restrictions should have an impact, in particular, in connection with the internationalization of the enterprise, which in the era of restrictions introduced by individual countries is currently a very big logistical and capital-intensive challenge. Pilot studies indicate, however, that the pandemic and the related global situation do not have any impact on the changes to the existing strategies related to the internationalization of the company. In connection with the implemented and/or planned internationalization process, the company introduces changes inside the organization, because they allow for the more effective implementation of tasks related to the internationalization process. In a situation where the enterprise changes the production structure, it is very often related to the changes made in the financing structure, which directly affects the change of the entire financial strategy of the enterprise. This is because the development of exports, which is part of the internationalization stage of the enterprise, increases the demand for products sold by the enterprise. The moment the products are exported beyond the borders of the home country, the company does not stop selling its products on the domestic market. Greater demand causes the necessity to make changes in the production structure - an increase in demand for the products offered by the enterprise is assumed. Therefore, increasing the production capacity requires additional financial outlays to achieve the planned production level. During the conducted pilot studies, enterprises declared their willingness to change the financial structure in connection with the willingness to obtain financing from the new program perspective of EU funds. It should also be noted that enterprises are willing to create special purpose funds for which they allocate a large part of their capital, indirectly used at various stages of internationalization such as the development of a machine park or increasing production capacity, which are later used in the implementation of export products for foreign markets. Based on the conducted pilot studies, it should be concluded that the established hypothesis is correct. However, it is necessary to conduct further research on a representative sample of enterprises to determine whether or not to accept the hypothesis. 


\section{References}

Barłożewski, K. (2017). Wpływ ekspansji zagranicznej na efektywność przedsiębiorstw. Warszawa: Wydawnictwo C.H. Beck.

Baronchelli, G., \& Cassia, F. (2010). Drivers of born global companies'international development: An empirical investigation among Italian companies (10th Global Conference on Business and Economics). Rome.

Bojar, E. (2001). Bezpośrednie inwestycje zagraniczne w obszarach słabo rozwiniętych. Warszawa: Wydawnictwo Naukowe PWN.

Burgman, T. A. (1996). An empirical examination of multinational corporate capital structure. Journal of International Business Studies, 27(3).

Chen, C. J. P., Cheng, C. S. A., He, J., \& Kim, J. (1997). An investigation of the relationship between international activities and capital structure. Journal of International Business Studies, 28(30).

Chkir, I. E., \& Cosset J. -C. (2001). Diversification strategy and capital structure of multinational corporations. Journal of Multinational Financial Management, 11(1).

Chiung-Jung, Ch., \& Chwo-Ming, J. (2011). Managerial ownership, diversification, and firm performance: Evidence from an emerging market. International Business Review, 21(3).

Dorożyński, D. (2018). Wspieranie zagranicznych inwestycji bezpośrednich w Polsce przez system zachęt dla inwestorów. Łódź: Wydawnictwo Uniwersytetu Łódzkiego.

Doukas, J. A., \& Pantzalis, C. (2003). Geographic diversification and agency costs of debt of multinational firms. Journal of Corporate Finance, 9(1).

Dunning, J. \& Lundan, S. (2008). Theories of foreign direct investment. In J. Dunning \& S. Lundan (Eds.), Multinational enterprises and the global economy. Cheltenham: Edward Elgar Publishing Limited.

Elgar, E., \& Cheltenham Fatemi, A. M. (1988). The effect of international diversification on corporate financing policy. Journal of Business Research, 16.

Fatemi, A. M. (1988), The effect of international diversification on corporate financing policy. Journal of Busines Research, 16(1).

Frynas, J., \& Mellahi, K. (2011). Global strategic management. Oxford: Oxford University Press.

Gorynia, M. (2007). Strategie zagranicznej ekspansji przedsiębiorstw. Warszawa: PWE.

Główny Urząd Statystyczny [GUS]. (2019). Handel zagraniczny. Handel towarami wedtug cech przedsiębiorstw (TEC). Warszawa: Główny Urząd Statystyczny.

Hennart, J. (2007). Theoretical rationale for a multinationality - performance relationship. Management International Review, 47.

Hitt, M. A., Hoskisson, R. E., \& Kim, H. (1997). International diversification: Effects of innovation and firm performance in product - diversified firms. The Academy of Management Journal, 40(4).

Hodder, J. E., \& Senbet, L.W. (1990). International capital structure equilibrium. Journal of Finance, (45).

Hughes, J. S., De Louge, D., \& Seeney, R. J.(1975). Corporate international diversification and market assigned measure of risk and diversification. Journal of Financial and Quantitative Analysis, (10).

Jantunen, A., Nummela, N., Puumalainen, K., \& Caarenketo, S. (2008). Strategic orientations of born global - do they really matter? Journal of World Business, 4.

Jaworek, M. (2013). Ocena ekonomicznej efektywności bezpośrednich inwestycji zagranicznych w praktyce polskich przedsiębiorstw. Toruń: UMK.

Johanson, J. \& Vahlne, J. (1977). The internationalization process of the firm: A model of knowledge development and increasing market commitments. Journal of International Business Studies, 8.

Johanson, J. \& Vahlne, J. (2009). The Uppsala internationalization process model revisited: From liability of foreignness' to ability of outsidership. Journal of International Business Studies, 40.

Karaszewski, W. (Ed.). (2013). Aktywność inwestycyjna polskich przedsiębiorstw za granica. Czynniki i skutki. Warszawa: Wydawnictwo Naukowe PWN. 
Knight, G. \& Cavusgil, S. (2004). Innovation, organizational capabilities and the born global firm. Journal of International Business Studies, 35(9).

Lee, K.C. \& Kwok, C. C. Y. (1988). Multinational corporations vs. domestic corporations. International environmental factors and determinants of capital structure. Journal of International Business Studies, 19(2).

Michel, A. \& Shaked, I. (1986). Multinational corporations vs. domestic corporations: Financial performance and characteristic. Journal of International Business Studies, 17(3).

Poniatowska-Jaksch, M. \& Pakulska, T. (2009). Korporacje transnarodowe a globalne pozyskiwanie zasobów. Warszawa: SGH.

Plawgo, B., Chilimoniuk-Przeździecka, E., Klimczak, T., Miller, A. \& Rumińska, P. (2014). Ewaluacja potencjatu eksportowego przedsiębiorstw $w$ Polsce. Warszawa: PARP.

Różański, J. (2010). Przedsiębiorstwa zagraniczne w Polsce. Rozwój. Finansowanie. Ocena. Warszawa: PWE.

Rymarczyk, J. (2004). Internacjonalizacja i globalizacja przedsiębiorstw. Warszawa: PWE.

Shapiro, A. C. (1978). Financial structure and cost capital in the multinational corporation. Journal of Financial and Quantitive Analysis, 13.

Singh, M., \& Nejadmalayeri, A. (2004). Internationalization, capital structure, and cost of capital: Evidence from French corporations. Journal of Multinational Financial Management, 14(2).

Svatosova, V. (2017). Identification of financial strategy in small and medium - sized entrepreneurship. Acta Universitias Agriculture Et Silvicultuare Mendelianae Brunensis, 4.

Vissak, T. \& Francioni, B. (2013). Serial nonlinear internationalization in practice. A case study. International Business Review.

Welch, L. \& Luostarinen, R. (1988). Internationalization: Evolution of the concept. Journal of General Management, 14.

\section{STRATEGIA FINANSOWA A PROCES INTERNACJONALIZACJI PRZEDSIĘBIORSTW}

Streszczenie: W artykule przedstawiono badania pilotażowe dotyczące strategii finansowej przedsiębiorstw w procesie internacjonalizacji. Wykorzystując ankietę jako metodę badawczą, przeprowadzono 25 wywiadów z przedsiębiorstwami, które eksportują swoje produkty. Postawiona w artykule hipoteza ma nastepujące brzmienie: kryzys gospodarczy wywołany pandemią nie doprowadzi do zmiany znaczenia czynników kształtujących strategię finansową przedsiębiorstw, a w szczególności do zmiany relacji między internacjonalizacją a strategią finansową przedsiębiorstwa.

Słowa kluczowe: internacjonalizacja, przedsiębiorstwo, strategia finansowa. 